\title{
GLASS SELECTION STRATEGY: Development of US and KRI Test Matrices
}

\author{
A. Aloy \\ V. R. Khlopin Radium Institute \\ J.D. Vienna \\ Pacific Northwest National Laboratory \\ K.M. Fox, T.B. Edwards, and D.K. Peeler \\ Savannah River National Laboratory
}

September 2006

Process Science and Engineering Section Savannah River National Laboratory Aiken, SC 29808

Prepared for the U.S. Department of Energy Under Contract Number DEAC09-96SR18500

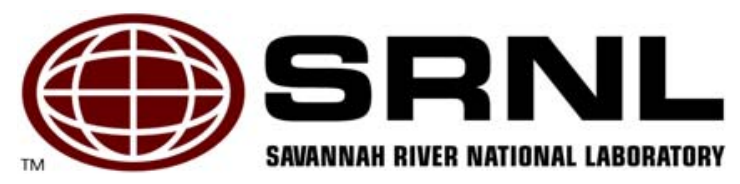


WSRC-STI-2006-00205

Revision 0

\section{DISCLAIMER}

This report was prepared by Washington Savannah River Company (WSRC) for the United States Department of Energy under Contract No. DE-AC09-96SR18500 and is an account of work performed under that contract. Neither the United States Department of Energy, nor WSRC, nor any of their employees makes any warranty, expressed or implied, or assumes any legal liability or responsibility for the accuracy, completeness, or usefulness, of any information, apparatus, or product or process disclosed herein or represents that its use will not infringe privately owned rights. Reference herein to any specific commercial product, process, or service by trademark, name, manufacturer or otherwise does not necessarily constitute or imply endorsement, recommendation, or favoring of same by WSRC or by the United States Government or any agency thereof. The views and opinions of the authors expressed herein do not necessarily state or reflect those of the United States Government or any agency thereof.

\section{Printed in the United States of America \\ Prepared For \\ U.S. Department of Energy}

The Savannah River National Laboratory is operated for the U.S. Department of Energy by Washington Savannah River Company. 
Keywords: high level waste, glass, aluminum, durability

Retention: permanent

\title{
GLASS SELECTION STRATEGY: Development of US and KRI Test Matrices
}

\author{
A. Aloy \\ V. R. Khlopin Radium Institute \\ J.D. Vienna \\ Pacific Northwest National Laboratory \\ K.M. Fox, T.B. Edwards, and D.K. Peeler \\ Savannah River National Laboratory
}

September 2006

Process Science and Engineering Section

Savannah River National Laboratory

Aiken, SC 29808

Prepared for the U.S. Department of Energy Under

Contract Number DEAC09-96SR18500

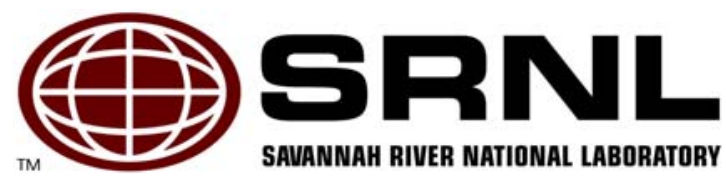




\section{REVIEWS AND APPROVALS}

\section{AUTHORS:}

K.M. Fox, Materials Science and Technology Section $1 / 29 / 07$

$\frac{1 / 29 / 07}{\text { T.B. Edwards, Statistical Consulting Section }}$

$\underset{\text { D.K. Peeler, Process Science and Engineering Section }}{1 / 29 / 07}$

\section{TECHNICAL REVIEWER:}

C.C. Herman, Manager, Process Engineering Technology Group $\quad 1 / 29 / 07$

\section{APPROVERS:}

R.E. Edwards, Manager, Process Science and Engitheering Section $2 / 6 / 07$

$\begin{array}{lc}\text { T.B. Calloway, Manager, Advanced Process Development } & 1 / 29 / 07 \\ \text { D.A. Crowley, Manager, Stabilization Sciegke Research } & \text { Date } \\ \text { D. } & \text { Date }\end{array}$


WSRC-STI-2006-00205

Revision 0

\section{EXECUTIVE SUMMARY}

High-level radioactive wastes are stored as liquids in underground storage tanks at the Department of Energy's (DOE) Savannah River Site (SRS) and Hanford Reservation. These wastes are to be prepared for permanent disposition in a geologic repository by vitrification with glass forming additives (e.g., frit), creating a waste form with long-term durability. Wastes at SRS are being vitrified in the Defense Waste Processing Facility (DWPF). Vitrification of the wastes stored at Hanford is planned for the Waste Treatment and Immobilization Plant (WTP) when completed. Some of the wastes at SRS, and particularly those at Hanford, contain high concentrations of aluminum, chromium and sulfate. These elements make it more difficult to produce a waste glass with a high waste loading (WL) without crystallization occurring in the glass (either within the melter or upon cooling of the glass), potentially exceeding the solubility limit of critical components, having negative impacts on durability, and/or resulting in the formation of a sulfate salt layer on the molten glass surface. Although the overall scope of the task is focused on all three critical, chemical components, the current work will primarily address the potential for crystallization (e.g., nepheline and/or spinel) in high level waste (HLW) glasses. Recent work at the Savannah River National Laboratory (SRNL) and by other groups has shown that nepheline $\left(\mathrm{NaAlSiO}_{4}\right)$, which is likely to crystallize in high-alumina glasses, has a detrimental effect on the durability of the glass.

The objective of this task is to develop glass formulations for specific SRS and Hanford waste streams to avoid nepheline formation while meeting waste loading and waste throughput expectations, as well as satisfying critical process and product performance related constraints. Secondary objectives of this task are to assess the sulfate solubility limit for the DWPF composition and spinel settling for the WTP composition. SRNL has partnered with Pacific Northwest National Laboratory (PNNL) and the V.G. Khlopin Radium Institute (KRI) to complete this task.

Prior to demonstrating the acceptability of specific glass compositions for both DWPF and WTP, a more fundamental understanding of the compositional - property relationships within the glass regions of interest to both sites is warranted. Through this basic understanding, models can be generated to aid in the development of the specific glasses to demonstrate improved WLs for the specific streams of interest while still meeting both process and product performance criteria. To meet this initial goal (a more fundamental understanding), projected glass compositional regions that bound anticipated DWPF and WTP glass regions of interest were developed and used to generate glass compositions of interest for this study. A thorough statistical analysis was employed to allow for a wide range of waste glass compositions to be examined while minimizing the number of glasses that must be fabricated and tested in the laboratory. Two test matrices resulted from this process and are referred to throughout this report as the US test matrix and the KRI test matrix. A total of 75 glasses define both matrices and will be used to assess critical compositional - property relationships from which the stated objectives can be met. Seven of the glasses will be fabricated and tested by both SRNL/PNNL and KRI to evaluate consistency between the labs (i.e., glasses targeting the same compositions are common to both matrices). SRNL/PNNL will fabricate and test a total of 45 glasses, and KRI will fabricate and test a total of 30 glasses. This report discusses the development of both the US and KRI test matrices.

The US test matrix glasses will be batched and melted following standard SRNL procedures, and testing will be completed to measure the chemical durability of each glass composition.

Fabrication and testing of the test matrix glasses at KRI will follow procedures that are equivalent 
to those at SRNL and PNNL. Data from the three laboratories will be monitored for consistency primarily by testing certified standard glasses and by fabricating and testing selected glasses with the same target compositions in both the US and KRI matrices (replication). Once complete, the data from these test matrix glasses will be compiled and used to formulate glasses for selected Hanford and SRS waste streams. These glasses will be tested at crucible scale and then selected compositions will be demonstrated at melter scale using the EP-5 melter at KRI. A subsequent report will document the results of the experimental portion of this study. 


\section{TABLE OF CONTENTS}

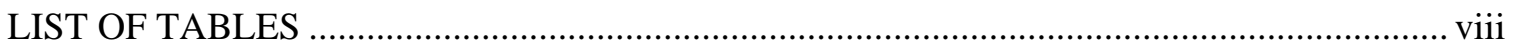

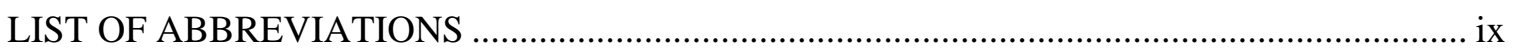

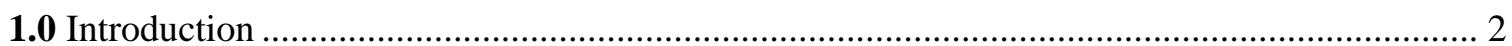

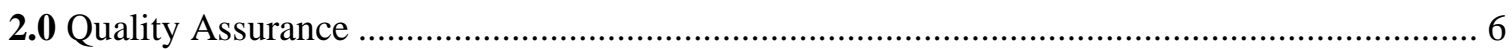

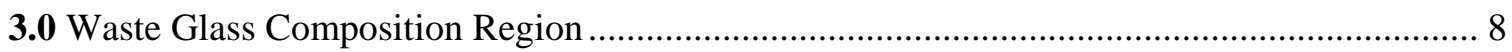

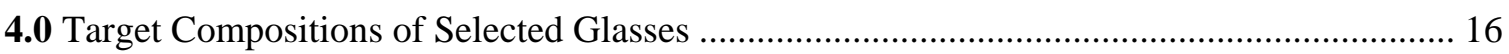

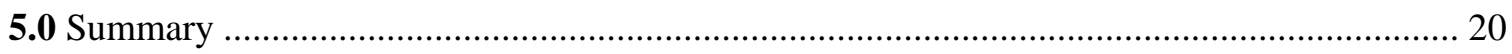

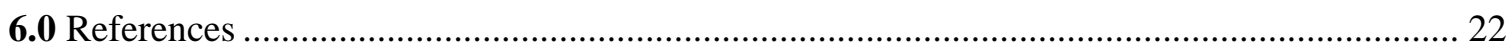




\section{LIST OF TABLES}

Table 3-1. Initial limits (as mass fractions) for DWPF and WTP waste glass compositions......... 9

Table 3-2. Preliminary Property-Composition Models ............................................................ 10

Table 3-3. Inner Layer Limits (as Mass Fractions) for DWPF and WTP Waste Glass

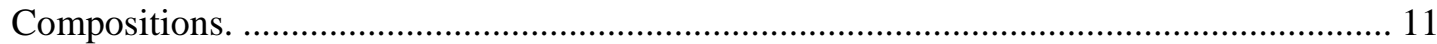

Table 4-1. Target Compositions (as Mass Fractions) of the Test Matrix Glasses........................ 17 


\section{LIST OF ABBREVIATIONS}

$\begin{array}{ll}\text { ARM } & \text { Approved Reference Material } \\ \text { DOE } & \text { Department of Energy } \\ \text { DOE-EM } & \text { Department of Energy - Environmental Management } \\ \text { DWPF } & \text { Defense Waste Processing Facility } \\ \text { EA } & \text { Environmental Assessment } \\ \text { EVs } & \text { Extreme Vertices } \\ \text { HLW } & \text { High Level Waste } \\ \text { KRI } & \text { V.G. Khlopin Radium Institute } \\ \text { LWO } & \text { Liquid Waste Organization } \\ \text { NQARD } & \text { Nuclear Quality Assurance Requirements and Description } \\ \text { PCT } & \text { Product Consistency Test } \\ \text { PNNL } & \text { Pacific Northwest National Laboratory } \\ \text { QA } & \text { Quality Assurance } \\ \text { SRNL } & \text { Savannah River National Laboratory } \\ \text { SRS } & \text { Savannah River Site } \\ \text { TCLP } & \text { Toxicity Characterization Leaching Procedure } \\ \text { WL } & \text { Waste Loading (weight percent) } \\ \text { WTP } & \text { Waste Treatment and Immobilization Plant }\end{array}$


WSRC-STI-2006-00205

Revision 0

This page intentionally left blank. 


\subsection{Introduction}

The U.S. Department of Energy (DOE) is currently processing (or planning to process) high-level waste (HLW) through Joule-heated melters at the Savannah River Site (SRS) and Hanford. Wastes at SRS are being vitrified in the Defense Waste Processing Facility (DWPF). Vitrification of the wastes stored at Hanford is planned for the Waste Treatment and Immobilization Plant (WTP) when completed. The process combines the HLW sludge with a prefritted additive or with mined, glass-forming minerals. The combination is subsequently melted, and the molten glass is poured into stainless steel canisters where it solidifies to create the final waste form. The compositions of these wastes vary depending on the process that generated them. Some of the wastes at SRS, and many of those at Hanford, contain high concentrations of aluminum, chromium and sulfate.

The projected concentrations of these elements in the waste make it more difficult to produce a waste glass with a high waste loading (WL) without crystallization occurring in the glass (either within the melter or upon cooling of the glass), potentially exceeding the solubility limit of critical components, and/or possibly forming a sulfate salt layer on the molten glass surface. Although the overall scope of the task is focused on all three critical components (aluminum, chromium and sulfate), the current work will primarily address solubility limits and the potential for crystallization (e.g., nepheline and/or spinel) in HLW glasses and their impact on processing and/or product performance criteria.

In preparation for the qualification and receipt of each sludge batch, various tank blending and/or washing strategies are often evaluated. The various strategies are contemplated in an effort to meet critical site objectives or constraints such as those associated with tank volume, transfer options, and/or settling issues. Although these objectives or constraints are critical, one must not lose sight of process and product performance issues associated with the final waste form. The product performance issue relates to the durability of the glass waste form. Process related issues (e.g., liquidus temperature, viscosity, electrical conductivity, and melt rate) are critical as they ultimately play a significant role in defining the efficiency and effectiveness of the melter operation.

Tank retrieval and blending strategies at both SRS and Hanford have identified high $\mathrm{Al}_{2} \mathrm{O}_{3}$ waste streams that are scheduled to be processed through their respective HLW vitrification facilities. For example, the Liquid Waste Organization (LWO) at SRS has provided compositional projections for the next two sludge batches (Sludge Batch 4 and Sludge Batch 5) to be processed in the DWPF. These streams have $\mathrm{Al}_{2} \mathrm{O}_{3}$ concentrations between approximately 25 and $40 \mathrm{wt} \%$ (on a calcined oxide basis). In addition, physical limitations in the Tank Farms and/or settling issues associated with the sludge have prevented "advanced" washing, which has resulted in relatively high $\mathrm{Na}_{2} \mathrm{O}$ (between $\sim 22-26 \mathrm{wt} \%$ ) and $\mathrm{SO}_{3}$ (between $\sim 0.8-1.6 \mathrm{wt} \%$ ) concentrations. Current Hanford projections suggest that the $\mathrm{Al}_{2} \mathrm{O}_{3}$ concentrations in sludge could be as high as $80 \mathrm{wt} \%$ (see Figure 1-1) - much greater than those currently projected for DWPF. 


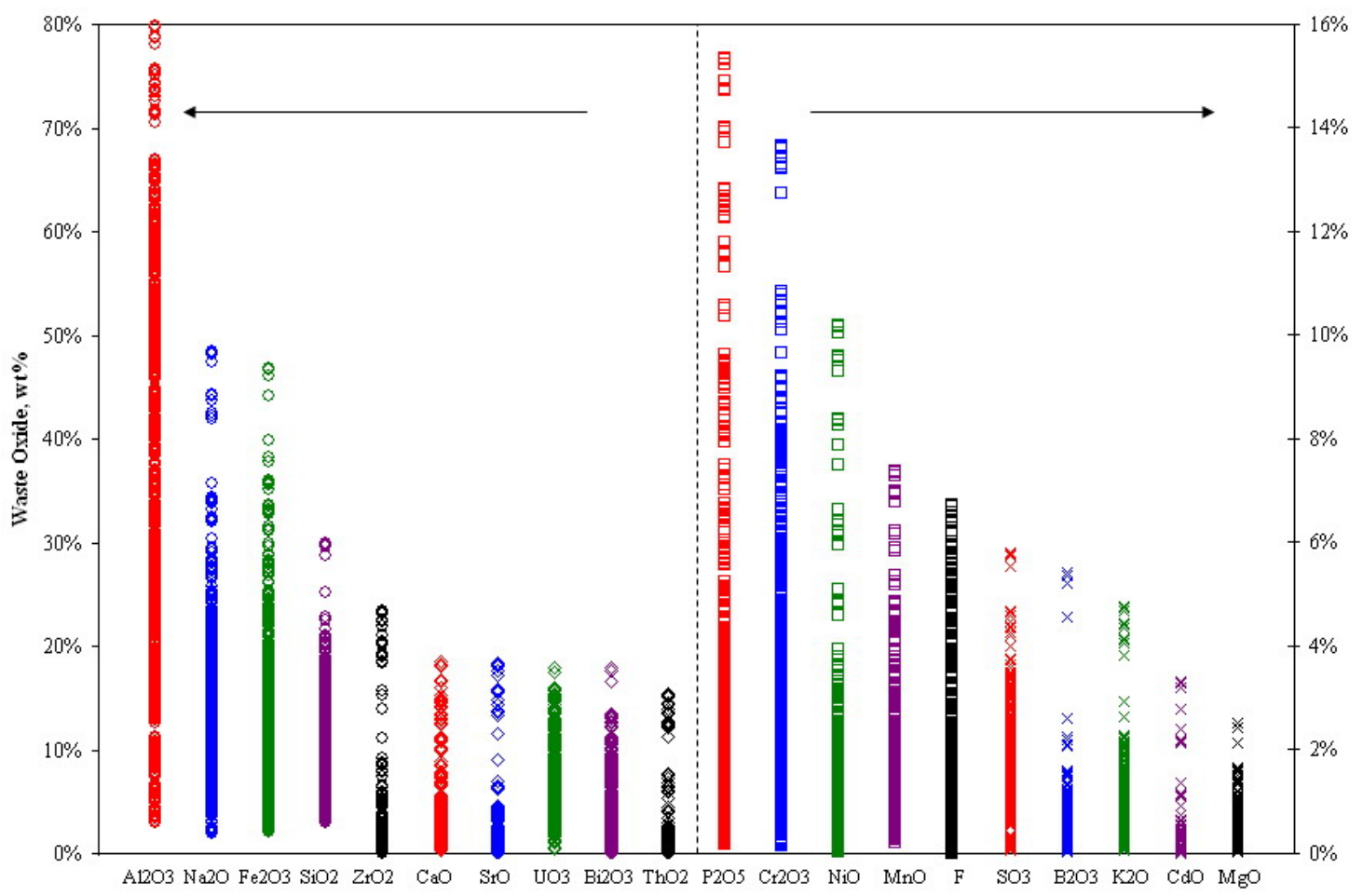

Figure 1-1. Range of Component Concentrations in Hanford Pretreated HLW Sludge

It is well known that the addition of small amounts of $\mathrm{Al}_{2} \mathrm{O}_{3}$ to borosilicate glasses generally enhances the durability of the waste form through creation of network-forming tetrahedral $\mathrm{Na}^{+}-\left[\mathrm{AlO}_{4 / 2}\right]^{-}$pairs. A nonbridging oxygen is removed from the glass structure and the Na satisfies the charge balance of the $\mathrm{AlO}_{4 / 2}$ tetrahedron. However, nepheline $\left(\mathrm{NaAlSiO}_{4}\right)$ formation, which depends in part on the $\mathrm{Al}_{2} \mathrm{O}_{3}$ content of the glass, can result in a severe deterioration of the chemical durability. The primary driver for the reduction in durability is the fact that nepheline removes three moles of glass forming oxides $\left(\mathrm{Al}_{2} \mathrm{O}_{3}\right.$ and $2 \mathrm{SiO}_{2}$ ) per each mole of $\mathrm{Na}_{2} \mathrm{O}$ from the continuous glass phase. Therefore, nepheline formation produces an $\mathrm{Al}_{2} \mathrm{O}_{3}$ and $\mathrm{SiO}_{2}$ deficient continuous glass matrix (relative to the same composition which is void of crystals) which reduces the durability of the final product. The magnitude of the reduction ultimately depends on the extent (e.g., volume \%) of crystallization and on the initial glass composition. Recent work at the Pacific Northwest National Laboratory (PNNL) and Savannah River National Laboratory (SRNL) has shown that nepheline which is likely to crystallize in high-alumina glasses, has a detrimental effect on durability of the glass. ${ }^{1-9}$

The formation of nepheline and/or other aluminum/silicon-containing crystals is a potential problem for both DWPF and WTP due to the projected compositional views recently evaluated, coupled with the frit development strategy (e.g., higher alkali frits have lead to enhanced melt rates at DWPF for recently processed sludge batches) and/or the desire to minimize sludge washing because of tank farm and/or evaporator issues. While durability is obviously a critical constraint that the HLW glass must meet, other important process related issues are also impacted by high concentrations of $\mathrm{Al}_{2} \mathrm{O}_{3}$. Higher concentrations of $\mathrm{Al}_{2} \mathrm{O}_{3}$ will generally increase the liquidus temperature of the melt and decrease the processing rate. 
As shown in Figure 1-1, upper $\mathrm{Cr}_{2} \mathrm{O}_{3}$ concentrations in sludge for Hanford are estimated to be on the order of $14 \%$. This high concentration could severely limit waste loadings due to crystallization and/or solubility issues. Therefore, a more fundamental assessment of $\mathrm{Cr}_{2} \mathrm{O}_{3}$ solubility and/or its impact on crystallization potential is of interest.

The objective of this task is to develop glass formulations for specific DOE waste streams (high $\mathrm{Al}_{2} \mathrm{O}_{3}$ and/or $\mathrm{Cr}_{2} \mathrm{O}_{3}$ ) that allow for higher waste loadings to be targeted without compromising waste throughput expectations, as described in the task plan. ${ }^{10}$ To meet this objective, an integrated test matrix has been developed from which compositional - property relationships will be determined over glass compositional regions of interest to both DWPF and WTP. A thorough statistical analysis has been employed to allow for a wide range of waste glass compositions to be examined while minimizing the number of glasses that must be fabricated in the laboratory. The selection of optimally designed glass compositions within the compositional regions of interest is detailed in this report. It should be noted that the test matrix glasses will not represent a specific DWPF or WTP flowsheet (i.e., a specific sludge composition coupled with a frit or glass formers at a specific waste loading). Instead, the glass compositions will be optimally selected within the regions of interest to each site to allow for general compositional - property relationships to be evaluated and ultimately modeled. The models will then be used to guide the glass formulation team to design specific glasses based on the sludge composition identified from each site.

SRNL/PNNL will fabricate and test a total of 45 glasses, and V.G. Khlopin Radium Institute (KRI) will fabricate and test a total of 30 glasses. Seven glasses will be fabricated and tested by both the United States contingent (SRNL and PNNL) and KRI to evaluate consistency among the labs. Based on the resulting data, glass formulations for specific DOE waste streams will be developed and tested in a pilot scale melter to demonstrate feasibility. This report summarizes the development of the integrated test matrix (i.e., the US and KRI matrices).

Secondary objectives of this DOE - Environmental Management (DOE-EM) related program are to assess the sulfate solubility limit for the DWPF composition and spinel settling for the WTP composition. These secondary objectives are not specifically addressed in this report. 
WSRC-STI-2006-00205

Revision 0

This page intentionally left blank. 
WSRC-STI-2006-00205

Revision 0

\subsection{Quality Assurance}

This project will be performed in accordance with the applicable criteria of 10 CFR 830.120, Subpart A, Quality Assurance Criteria and/or DOE/RW-0333P requirements. It should be recognized that SRNL and PNNL will be performing specific tasks associated with this work scope. The PNNL QA Program being implemented for this project is the Nuclear Quality Assurance Requirements and Description (NQARD) document. The NQARD is an NQA-1 based program (which meets DOE/RW-0333P requirements) with a graded approach for applying QA controls. The NQARD manual includes a program description section, followed by a set of QA implementing procedures. ${ }^{11}$ SRNL's work scope will be performed in accordance with 1Q, QAP with supplemental quality assurance requirements as defined by L1, 8.21, Supplemental QA Requirements for DOE/RW-0333P also being applied. Peeler et al. summarize the QA plan under which this study will be performed. ${ }^{10}$ In addition, the JMP software ${ }^{12}$ that will be used to support the development of the US and KRI test matrices is controlled under WSRC-RP99-00422, Software QA Plan and Verification \& Validation for Commercial Statistical Packages Utilized by the Statistical Consulting Section of SRNL.

It is recognized that SRNL and PNNL QA controls can not be placed on the work scope performed at KRI. To this end, the US and KRI test matrices have been developed to provide technically sound insight into the quality of the data developed by KRI. Specifically, seven replicate (or duplicate) glass compositions are targeted in both US and KRI matrices. These glasses will be independently batched, melted, and characterized by both countries. Internal standards or controls (e.g., the Environmental Assessment (EA) glass, the Approved Reference Material (ARM) glass, etc.) will be used in all appropriate testing as additional measures of control. KRI will also provide samples of each nonradioactive glass for compositional analysis which will be performed under the auspices of an approved analytical plan at SRNL. The resulting data will provide an assessment of the data quality and the possible use of additional KRI glasses to support model development and/or validation efforts. Prior to use of the KRI data, the data will be qualified in accordance to E7 3.70 "confirmatory testing" protocols (specifically paragraph 5.3.4). 
WSRC-STI-2006-00205

Revision 0

This page intentionally left blank. 


\subsection{Waste Glass Composition Region}

Two glass composition regions were developed for this DOE-EM high-alumina glass study: one anticipated to bound the waste form likely to be generated by DWPF and one to bound the waste form likely to be generated by WTP. The regions were determined by applying glass science theory to the compositional waste projections from Hanford and the LWO at SRS to identify major glass components and their concentration intervals for this study. The initial concentration limits for the major oxides in the DWPF and WTP glass regions are listed in Table 3-1. Note that the DWPF interval for each oxide is contained within the corresponding WTP interval for that oxide. Thus, the WTP region is bounding the region defined for DWPF. As glasses are selected for this study, an effort was made to ensure that some of the glasses are of direct interest to the operation of DWPF as well as to the operation of WTP. Other glasses, which are outside of the glass region of interest to DWPF, will be selected for study to fully explore the region of interest to WTP. A layered approach will be used in selecting compositions to cover the regions defined by the intervals of Table 3-1. Specifically, an approach will be used to select glasses from the region of interest to DWPF and then additional glasses will be selected to complement those in covering the region of interest for WTP.

Consideration was given to using these matrices to augment previously generated data. Databases of existing composition/properties data for SRS and Hanford waste glasses ${ }^{13,14}$ were queried to determine if any existing data overlap the compositional region of interest for this study. Few if any glasses in the databases were found covering this region. Therefore, glasses will be fabricated and characterized in the laboratory to satisfy the objectives of this study. 
Table 3-1. Initial limits (as mass fractions) for DWPF and WTP waste glass compositions.

\begin{tabular}{|c|c|c|c|c||}
\hline \multirow{2}{*}{ Oxide } & \multicolumn{2}{|c|}{$\begin{array}{c}\text { DWPF Initial Limits } \\
\text { Lower }\end{array}$} & \multicolumn{2}{c|}{$\begin{array}{c}\text { WTP Initial Limits } \\
\text { Lower }\end{array}$} \\
& 0.100 & 0.160 & 0.100 & 0.200 \\
$\mathrm{Al}_{2} \mathrm{O}_{3}$ & 0.050 & 0.200 & 0.050 & 0.200 \\
$\mathrm{~B}_{2} \mathrm{O}_{3}$ & 0.000 & 0.010 & 0.000 & 0.010 \\
$\mathrm{CaO}$ & 0.000 & 0.003 & 0.000 & 0.010 \\
$\mathrm{Cr}_{2} \mathrm{O}_{3}$ & 0.050 & 0.120 & 0.050 & 0.170 \\
$\mathrm{Fe}_{2} \mathrm{O}_{3}$ & 0.000 & 0.010 & 0.000 & 0.010 \\
$\mathrm{~K}_{2} \mathrm{O}$ & 0.020 & 0.060 & 0.020 & 0.060 \\
$\mathrm{Li} 2$ & 0.000 & 0.005 & 0.000 & 0.005 \\
$\mathrm{MgO}$ & 0.000 & 0.030 & 0.000 & 0.040 \\
$\mathrm{MnO}$ & 0.050 & 0.150 & 0.050 & 0.200 \\
$\mathrm{Na}{ }_{2} \mathrm{O}$ & 0.000 & 0.020 & 0.000 & 0.030 \\
$\mathrm{NiO}$ & 0.000 & 0.001 & 0.000 & 0.010 \\
$\mathrm{PbO}$ & 0.000 & 0.005 & 0.000 & 0.005 \\
$\mathrm{SO}$ & 0.350 & 0.500 & 0.350 & 0.500 \\
$\mathrm{SiO}$ & 0.000 & 0.001 & 0.000 & 0.030 \\
$\mathrm{SrO}_{\mathrm{TiO}}$ & 0.000 & 0.010 & 0.000 & 0.010 \\
$\mathrm{ZnO}$ & 0.000 & 0.001 & 0.000 & 0.020 \\
$\mathrm{ZrO}_{2}$ & 0.000 & 0.005 & 0.000 & 0.040 \\
\hline
\end{tabular}

To facilitate the selection of glass compositions that are likely to be processed from these regions, additional constraints were imposed on the glass regions defined by Table 3-1. The constraints were based on a set of preliminary models for WTP that relate the process (i.e., viscosity and liquidus temperature) and product (i.e., durability as measured by the Product Consistency Test (PCT)) properties of a glass to its chemical composition.

Table 3-2 provides models for the durability response for boron as a natural logarithm $(\ln (\mathrm{rB})) \mathrm{in} \mathrm{g} / \mathrm{m}^{2}$, for the liquidus temperature $\left(\mathrm{T}_{\mathrm{L}}\right)$ in degrees Celsius, and for the natural logarithm of viscosity in $\mathrm{Pa} \cdot \mathrm{s}$. For each of these models, the table provides the coefficient that relates the influence of the indicated glass oxide concentration (as a mass fraction) on the property being predicted. It is not suggested that these models are intended for use at WTP, but they are currently available and there is merit to their use in refining the glass region from which glasses are selected for this study. The $\ln (\mathrm{rB})$ model was used to restrict glass compositions to those for which the model's predictions were less than $6 \mathrm{~g} / \mathrm{m}^{2}$ or 1.7918 as a natural logarithm. For the $\mathrm{T}_{\mathrm{L}}$ model, the glass compositions were restricted to those that yielded a predicted liquidus temperature of no more than $1050{ }^{\circ} \mathrm{C}$ for glasses being selected for DWPF and of no more than $1150^{\circ} \mathrm{C}$ for WTP glasses. For viscosity, both a lower limit (1 Pa·s or 0 as a natural logarithm) and an upper limit (12 Pa·s or 2.4849 as a natural logarithm) were imposed on the property predictions. As indicated in Table 3-2, these limits were also adjusted by the intercept terms of the preliminary models as necessary.

Also, note that $\mathrm{UO}_{3}$ is listed as an oxide in this table, a select number of glass compositions containing this oxide will be introduced into the study in the discussion that follows. 
Table 3-2. Preliminary Property-Composition Models

\begin{tabular}{|c|c|c|c|c|c|}
\hline & & & \multicolumn{2}{|c|}{$\ln (\mathrm{h} 1150)$} & \\
\hline Oxides & $\ln (\mathrm{rB})$ & $\mathrm{T}_{\mathrm{L}}$ & lower & upper & \\
\hline $\mathrm{Al}_{2} \mathrm{O}_{3}$ & -18.63707 & 1814.337 & 11.989758 & 11.989758 & \\
\hline $\mathrm{B}_{2} \mathrm{O}_{3}$ & 12.862144 & -1191.372 & -10.30351 & -10.30351 & \\
\hline $\mathrm{CaO}$ & -12.87355 & 0 & -8.01534 & -8.01534 & \\
\hline $\mathrm{Cr}_{2} \mathrm{O}_{3}$ & 0 & 21087.77 & 0 & 0 & \\
\hline $\mathrm{Fe}_{2} \mathrm{O}_{3}$ & -4.307845 & 1501.0718 & -1.726499 & -1.726499 & \\
\hline $\mathrm{K}_{2} \mathrm{O}$ & 6.547366 & -1717.416 & -6.878158 & -6.878158 & \\
\hline $\mathrm{Li}_{2} \mathrm{O}$ & 20.275603 & -2433.262 & -38.86379 & -38.86379 & \\
\hline $\mathrm{MgO}$ & 10.055046 & 1922.7847 & -4.788365 & -4.788365 & \\
\hline $\mathrm{MnO}$ & -16.7143 & 271.95819 & -5.351132 & -5.351132 & \\
\hline $\mathrm{Na}_{2} \mathrm{O}$ & 11.98794 & -2259.142 & -12.59089 & -12.59089 & \\
\hline $\mathrm{NiO}$ & 27.753666 & 8155.7044 & 0 & 0 & \\
\hline $\mathrm{PbO}$ & 0 & 0 & 0 & 0 & \\
\hline $\mathrm{SO}_{3}$ & 59.107357 & 0 & 0 & 0 & \\
\hline $\mathrm{SiO}_{2}$ & -4.562846 & -226.9461 & 8.3094277 & 8.3094277 & \\
\hline $\mathrm{SrO}$ & -3.487065 & 0 & -5.810496 & -5.810496 & \\
\hline $\mathrm{TiO}_{2}$ & -22.31993 & 0 & -7.314341 & -7.314341 & \\
\hline $\mathrm{UO}_{3}$ & 0 & 405.04359 & 0 & 0 & \\
\hline $\mathrm{ZnO}$ & -2.301446 & 0 & 0 & 0 & \\
\hline $\mathrm{ZrO}_{2}$ & -10.77681 & 1199.2389 & 6.7616699 & 6.7616699 & \\
\hline & $<$ & $<$ & $>$ & $<$ & \\
\hline Limit & 1.7918 & 1050 & 0 & 2.4849 & \\
\hline Intercept & 0 & 1188.4476 & 1.3578933 & 1.3578933 & DWPF \\
\hline $\begin{array}{c}\text { Adjusted } \\
\text { Limit } \\
\end{array}$ & 1.7918 & -138.4476 & -1.3578933 & 1.12701335 & \\
\hline Limit & 1.7918 & 1150 & 0 & 2.4849 & \\
\hline Intercept & 0 & 1188.4476 & 1.3578933 & 1.3578933 & WTP \\
\hline $\begin{array}{l}\text { Adjusted } \\
\text { Limit }\end{array}$ & 1.7918 & -38.4476 & -1.3578933 & 1.12701335 & \\
\hline
\end{tabular}

The two sets of initial limits in Table 3-1 may be considered as defining the outer layers for the glass regions for DWPF and for WTP, respectively. Selecting glass compositions from the extremes of each of these regions, even with the constraints of Table 3-2 imposed, may lead to some glasses that are not likely to be processed at the corresponding facility. To limit the impact of this possibility, a modification was made to the approach for selecting glasses by adding an inner layer of oxide concentrations for each of the facilities. An inner layer for each oxide for each facility was determined by taking the middle $50 \%$ of the corresponding initial limits (outer layer). The inner layer limits or intervals for DWPF and WTP are listed in Table 3-3, and they will facilitate the selection of glasses for two more layers of compositional coverage to the regions of interest for DWPF and WTP. 
Table 3-3. Inner Layer Limits (as Mass Fractions) for DWPF and WTP Waste Glass Compositions.

\begin{tabular}{|c|c|c|c|c||}
\hline \multirow{2}{*}{ Oxides } & \multicolumn{2}{|c|}{$\begin{array}{c}\text { DWPF Inner Layer Limits } \\
\text { Lower }\end{array}$} & \multicolumn{2}{c|}{$\begin{array}{c}\text { WTP Inner Layer Limits } \\
\text { Lower }\end{array}$} \\
\hline $\mathrm{Al}_{2} \mathrm{O}_{3}$ & 0.11500 & 0.14500 & 0.12500 & 0.17500 \\
\hline $\mathrm{B}_{2} \mathrm{O}_{3}$ & 0.08750 & 0.16250 & 0.08750 & 0.16250 \\
\hline $\mathrm{CaO}$ & 0.00250 & 0.00750 & 0.00250 & 0.00750 \\
\hline $\mathrm{Cr}_{2} \mathrm{O}_{3}$ & 0.00075 & 0.00225 & 0.00250 & 0.00750 \\
\hline $\mathrm{Fe}_{2} \mathrm{O}_{3}$ & 0.06750 & 0.10250 & 0.08000 & 0.14000 \\
\hline $\mathrm{K}_{2} \mathrm{O}$ & 0.00250 & 0.00750 & 0.00250 & 0.00750 \\
\hline $\mathrm{Li}_{2} \mathrm{O}$ & 0.03000 & 0.05000 & 0.03000 & 0.05000 \\
\hline $\mathrm{MgO}$ & 0.00125 & 0.00375 & 0.00125 & 0.00375 \\
\hline $\mathrm{MnO}$ & 0.00750 & 0.02250 & 0.01000 & 0.03000 \\
\hline $\mathrm{Na} \mathrm{O}$ & 0.07500 & 0.12500 & 0.08750 & 0.16250 \\
\hline $\mathrm{NiO}$ & 0.00500 & 0.01500 & 0.00750 & 0.02250 \\
\hline $\mathrm{PbO}$ & 0.00025 & 0.00075 & 0.00250 & 0.00750 \\
\hline $\mathrm{SO} \mathrm{S}_{3}$ & 0.00125 & 0.00375 & 0.00125 & 0.00375 \\
\hline $\mathrm{SiO}{ }_{2}$ & 0.38750 & 0.46250 & 0.38750 & 0.46250 \\
\hline $\mathrm{SrO}_{\mathrm{TiO}}$ & 0.00025 & 0.00075 & 0.00750 & 0.02250 \\
\hline $\mathrm{ZnO}$ & 0.00250 & 0.00750 & 0.00250 & 0.00750 \\
\hline $\mathrm{ZrO}{ }_{2}$ & 0.00025 & 0.00075 & 0.00500 & 0.01500 \\
\hline
\end{tabular}

What does it mean for a glass composition to fall within the DWPF inner layer limits? A glass composition is in this region if its concentration for each oxide is between the inner layer upper and lower limits for that oxide (e.g., the $\mathrm{Al}_{2} \mathrm{O}_{3}$ concentration in the glass as a mass fraction is between 0.115 and 0.145 ) and the sum of the mass fractions of all 18 oxides of Table 3-3 equals 1 . Thus, the glass composition is a mixture, ${ }^{15}$ and selecting glasses from this inner layer, with the constraints of Table 3-2 imposed, may be thought of as developing a design for a constrained mixture experiment.

The traditional approach to developing these experimental designs is to generate a set of candidate points covering the region of interest and then to optimally select a design of a desired size, $n$. The goal is to find the set of $n$ design points that optimize a specific design criterion relative to a specified model of interest. A linear model of the 18 oxides will be used in selecting glass compositions for this study. ${ }^{\text {a }}$ One design criterion that is frequently used is the D-optimal design criterion. For this criterion, the goal of the design is to minimize the $\left|\left(\mathrm{X}^{\mathrm{T}} \mathrm{X}\right)^{-1}\right|$, where $\mathrm{X}$ is the design matrix, with each row of $\mathrm{X}$ a design point, i.e., a set of concentrations of the 18 oxides that defines a mixture and satisfies the constraints of Table 3-2. While this approach has been employed successfully, it becomes much more demanding of computer resources for generating and storing the candidate points required for the design as the number of oxides and the number of constraints increase.

Another approach for constrained mixture experimental designs that does not require an explicit set of candidate points is a customized version of the coordinate-exchange algorithm ${ }^{16}$ that is available in JMP Version 5.1.2. ${ }^{12}$ A description of this algorithm and of its use to construct a layered, mixture experiment design is provided by Piepel, Cooley, and Jones. ${ }^{17}$ It is this approach that was used to support the layered mixture experiment design for the DOE high-alumina glass study.

First, an initial set of 18 individual compositions were selected from the DWPF outer layer limits of Table 3-1 with the constraints of Table 3-2 imposed using the Custom Design option of JMP

\footnotetext{
${ }^{\text {a }}$ For layered designs, the approach of using a linear model of the oxides is typically employed.
} 
Version 5.1.2's Design of Experiment platform. The 18 design points were selected using the D-Optimal design criterion for a linear model in the 18 oxides and 10 different starting designs. The average of these 18 points, the centroid of these compositions, was also determined and added as a design point. Next, a set of 5 additional glass compositions was selected from the DWPF inner layer limits of Table 3-3, with the constraints of Table 3-2 imposed, using the Augment Design of JMP Version 5.1.2's Design of Experiment platform to D-Optimally complement the initial set of 18 design points. Next, a set of 18 additional glass compositions was selected from the WTP outer layer limits of Table 3-1 with the constraints of Table 3-2 imposed, once again using the Augment Design option to D-Optimally complement the set of 24 design points. The average of these 18 points from the WTP outer layer, the centroid of these compositions, was also determined and added as a design point. Next, a set of 18 additional glass compositions was selected from the WTP inner layer limits of Table 3-3 with the constraints of Table 3-2 imposed, once again using the Augment Design option to D-Optimally complement the set of 24 design points. Finally, 5 glasses were selected from the WTP outer layer with the addition of $\mathrm{UO}_{3}$ in the range of 0 to $8 \mathrm{wt} \%$. A total of 66 glasses were selected using this strategy, including the DWPF and WTP outer layer centroid compositions.

Figure 3-1 provides a plot of the concentrations as mass fractions of the design points by oxide and grouped by design layer. In the labels for the design layer, the outer layer EV points are outer layer extreme vertices (or corner-points of the region defined by outer layer limits with the model constraints imposed) and the inner layer points are inner layer extreme vertices. 
WSRC-STI-2006-00205

Revision 0

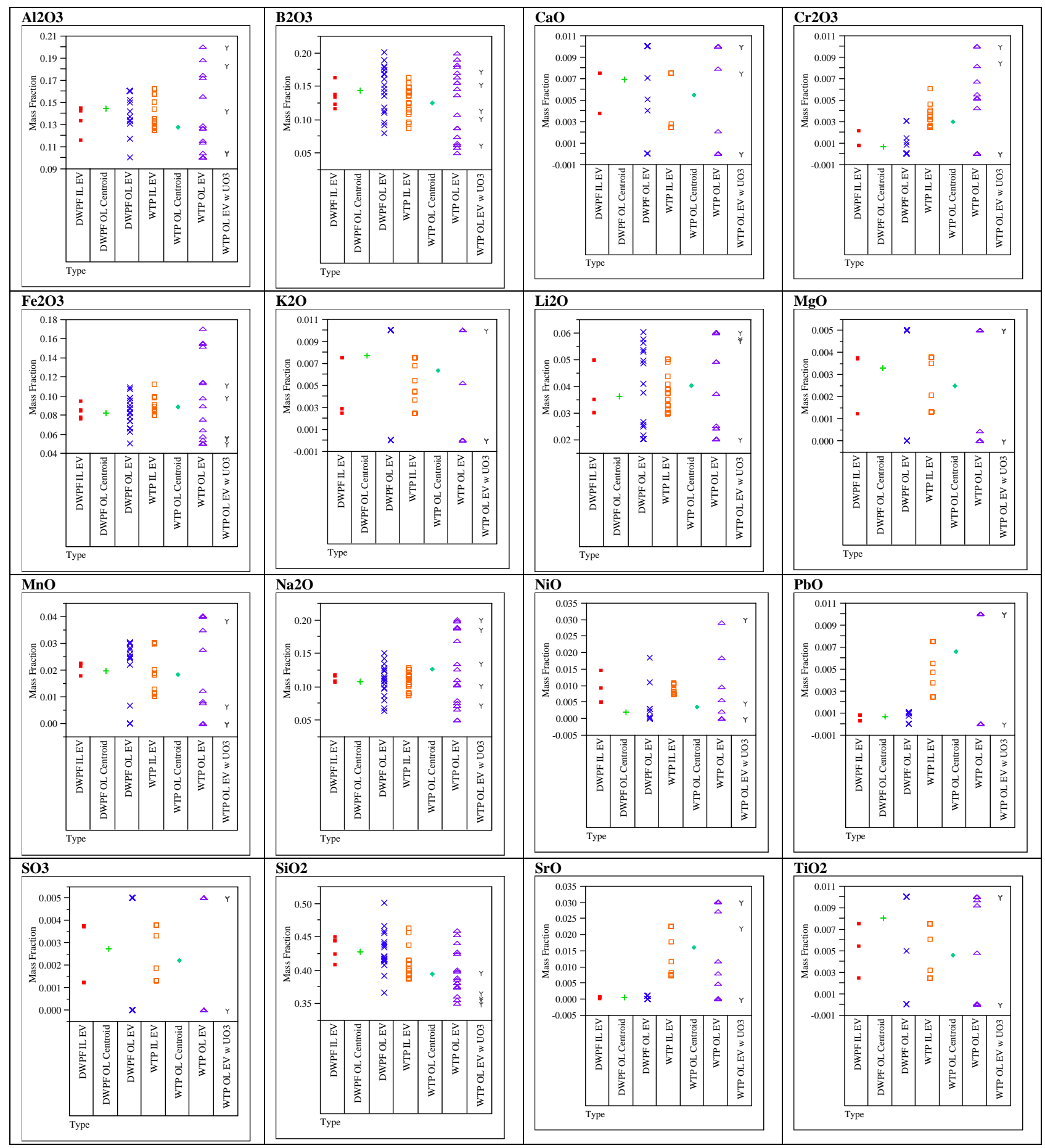

Figure 3-1. Plot of Oxide Concentrations for Design Points by Oxide and Grouped by Design Layer 


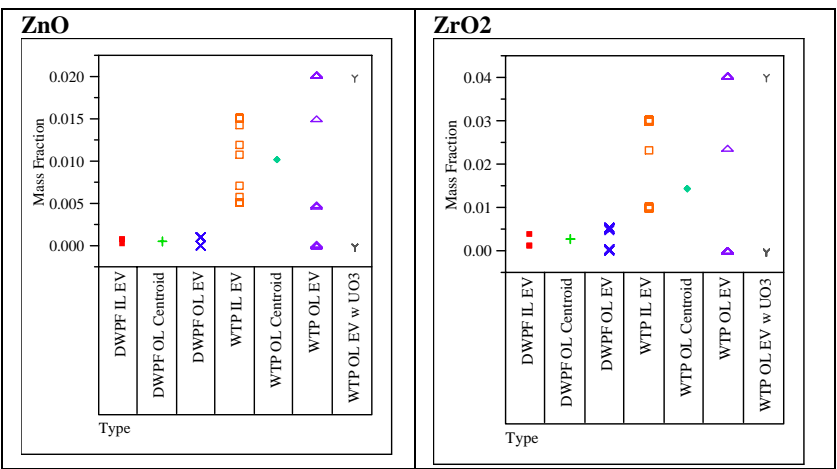

Figure 3-1. Plot of Oxide Concentrations for Design Points by Oxide and Grouped by Design Layer (continued)

It should be noted that prior to finalizing the 66 glass test matrix, a search was performed using JMP to determine if any glasses within the ComPro ${ }^{\mathrm{TM}}$ and Nepheline glass composition/properties databases ${ }^{13,14}$ could be used to support this study. However, the glass compositions selected as described above were all found to fall in a compositional region that is outside the range covered by SRNL's existing databases. 
WSRC-STI-2006-00205

Revision 0

This page intentionally left blank. 


\subsection{Target Compositions of Selected Glasses}

The target compositions of the glasses selected for this study are listed in Table 4-1. The glass identifiers presented on the left side of the table indicate the lab which will be fabricating the glass (US- $x x$ for SRNL and KRI- $x x$ for KRI). SRNL will fabricate the glasses chosen from the DWPF outer layer (US-01 through US-18), the glasses chosen from the DWPF inner layer (US-21 through US-25), and the glasses chosen from the WTP outer layer (US-26 through US-43). Duplicates of one glass from each of these three groups will be made at KRI as a check of consistency. KRI will fabricate the glasses chosen from the WTP inner layer (KRI-08 through KRI-25) and all of the WTP outer layer, uranium containing glasses (KRI-26 through KRI-30). Each lab will make two replicates of both the DWPF and WTP centroid glasses (US-19/KRI-02, US-20/KRI-03, US-44/KRI-06, and US-45/KRI-07).

Each test matrix glass will be prepared from the proper proportions of reagent-grade metal oxides, carbonates, $\mathrm{H}_{3} \mathrm{BO}_{3}$, and salts to produce sufficient glass for the associated testing (typically $300 \mathrm{~g}$ ). In general, the raw materials will be thoroughly mixed and placed into a platinum-alloy crucible (Pt, $\mathrm{Pt} / \mathrm{Rh}$, $\mathrm{Pt} / \mathrm{Au}$, etc.). The batch will be placed into a high-temperature furnace at the target melt temperature of $1150^{\circ} \mathrm{C}$. After an isothermal hold at $1150^{\circ} \mathrm{C}$ for 2 hours, the crucible will be removed, and the glass will be poured onto a clean stainless steel plate and allowed to air cool (quench). ${ }^{\text {a }}$ The glass pour patty will be used as a sampling stock for the various property measurements (i.e., PCT, $\mathrm{T}_{\mathrm{L}}$, viscosity, electrical conductivity, toxicity characterization leaching procedure [TCLP], and chemical composition) as defined in the associated SRNL and PNNL test plans. ${ }^{10,18}$

\footnotetext{
${ }^{a}$ It should be noted that higher melt temperatures may be required to ensure complete incorporation of all raw materials. If higher melt temperatures are required, the revised melt temperatures will be documented appropriately.
} 
Table 4-1. Target Compositions (as Mass Fractions) of the Test Matrix Glasses.

\begin{tabular}{|c|c|c|c|c|c|c|c|c|c|c|c|c|c|c|c|c|c|c|c|c|c|}
\hline \multicolumn{2}{|c|}{ Glass Identifiers } & \multirow{2}{*}{$\frac{\mathrm{Al}_{2} \mathbf{O}_{3}}{0.1493}$} & \multirow{2}{*}{$\frac{\mathbf{B}_{\mathbf{2}} \mathbf{O}_{3}}{0.0789}$} & \multirow{2}{*}{$\frac{\mathrm{CaO}}{0.0000}$} & \multirow{2}{*}{$\begin{array}{l}\mathrm{Cr}_{2} \mathbf{O}_{3} \\
0.0030\end{array}$} & \multirow{2}{*}{$\begin{array}{l}\mathbf{F e}_{2} \mathbf{O}_{3} \\
0.0859\end{array}$} & \multirow{2}{*}{$\begin{array}{c}\mathbf{K}_{\mathbf{2}} \mathbf{O} \\
0.0100\end{array}$} & \multirow{2}{*}{$\begin{array}{c}\mathrm{Li}_{2} \mathbf{O} \\
0.0562\end{array}$} & \multirow{2}{*}{$\begin{array}{c}\text { MgO } \\
0.0050\end{array}$} & \multirow{2}{*}{$\begin{array}{c}\text { MnO } \\
0.0250\end{array}$} & \multirow{2}{*}{$\begin{array}{l}\mathrm{Na}_{\mathbf{2}} \mathbf{O} \\
0.1237\end{array}$} & \multirow{2}{*}{$\begin{array}{c}\mathrm{NiO} \\
0.0006 \\
\end{array}$} & PbO & $\mathrm{RuO}_{2}{ }^{\mathrm{a}}$ & $\mathrm{SO}_{3}$ & $\mathrm{SiO}_{2}$ & SrO & $\mathrm{TiO}_{2}$ & $\mathrm{UO}_{3}$ & $\mathrm{ZnO}$ & $\mathrm{ZrO}_{2}$ \\
\hline US-01 & & & & & & & & & & & & & 0.0010 & 0.0002 & 0.0000 & 0.4553 & 0.0010 & 0.0000 & 0.0000 & 0.0000 & 0.0050 \\
\hline US-02 & & 0.1600 & 0.1686 & 0.0000 & 0.0000 & 0.0659 & 0.0000 & 0.0529 & 0.0000 & 0.0063 & 0.1233 & 0.0000 & 0.0000 & 0.0002 & 0.0000 & 0.4168 & 0.0000 & 0.0000 & 0.0000 & 0.0010 & 0.0050 \\
\hline US-03 & & 0.1600 & 0.1731 & 0.0100 & 0.0000 & 0.0653 & 0.0100 & 0.0407 & 0.0050 & 0.0000 & 0.0788 & 0.0029 & 0.0010 & 0.0002 & 0.0000 & 0.4421 & 0.0010 & 0.0100 & 0.0000 & 0.0000 & 0.0000 \\
\hline US-04 & & 0.1600 & 0.1129 & 0.0100 & 0.0000 & 0.0827 & 0.0100 & 0.0374 & 0.0050 & 0.0219 & 0.1033 & 0.0000 & 0.0010 & 0.0002 & 0.0050 & 0.4338 & 0.0010 & 0.0100 & 0.0000 & 0.0010 & 0.0050 \\
\hline US- 05 & & 0.1599 & 0.1670 & 0.0070 & 0.0000 & 0.0816 & 0.0100 & 0.0200 & 0.0050 & 0.0241 & 0.0958 & 0.0000 & 0.0010 & 0.0002 & 0.0050 & 0.4064 & 0.0010 & 0.0100 & 0.0000 & 0.0010 & 0.0050 \\
\hline US-06 & & 0.1600 & 0.1406 & 0.0100 & 0.0000 & 0.0815 & 0.0100 & 0.0247 & 0.0050 & 0.0300 & 0.1078 & 0.0000 & 0.0000 & 0.0002 & 0.0050 & 0.4142 & 0.0010 & 0.0100 & 0.0000 & 0.0000 & 0.0000 \\
\hline US-07 & & 0.1600 & 0.1349 & 0.0100 & 0.0000 & 0.0730 & 0.0100 & 0.0266 & 0.0050 & 0.0300 & 0.1067 & 0.0020 & 0.0010 & 0.0002 & 0.0050 & 0.4188 & 0.0010 & 0.0100 & 0.0000 & 0.0010 & 0.0050 \\
\hline US-08 & KRI-01 & 0.1519 & 0.0956 & 0.0000 & 0.0000 & 0.0975 & 0.0100 & 0.0486 & 0.0000 & 0.0244 & 0.0981 & 0.0000 & 0.0010 & 0.0002 & 0.0050 & 0.4577 & 0.0000 & 0.0100 & 0.0000 & 0.0000 & 0.0000 \\
\hline US-09 & & 0.1337 & 0.1505 & 0.0100 & 0.0030 & 0.1088 & 0.0000 & 0.0200 & 0.0050 & 0.0000 & 0.1411 & 0.0000 & 0.0010 & 0.0002 & 0.0050 & 0.4117 & 0.0000 & 0.0100 & 0.0000 & 0.0000 & 0.0000 \\
\hline US-10 & & 0.1412 & 0.1099 & 0.0100 & 0.0000 & 0.1069 & 0.0100 & 0.0200 & 0.0050 & 0.0274 & 0.1267 & 0.0000 & 0.0010 & 0.0002 & 0.0050 & 0.4198 & 0.0010 & 0.0100 & 0.0000 & 0.0010 & 0.0050 \\
\hline US-11 & & 0.1370 & 0.1998 & 0.0100 & 0.0000 & 0.0776 & 0.0100 & 0.0200 & 0.0050 & 0.0300 & 0.0669 & 0.0000 & 0.0010 & 0.0002 & 0.0050 & 0.4366 & 0.0000 & 0.0000 & 0.0000 & 0.0010 & 0.0000 \\
\hline US-12 & & 0.1324 & 0.1608 & 0.0100 & 0.0014 & 0.0874 & 0.0100 & 0.0600 & 0.0000 & 0.0000 & 0.1116 & 0.0184 & 0.0000 & 0.0002 & 0.0050 & 0.3913 & 0.0010 & 0.0050 & 0.0000 & 0.0010 & 0.0045 \\
\hline US-13 & & 0.1600 & 0.1457 & 0.0100 & 0.0000 & 0.0730 & 0.0100 & 0.0215 & 0.0050 & 0.0280 & 0.1153 & 0.0028 & 0.0010 & 0.0002 & 0.0000 & 0.4165 & 0.0000 & 0.0100 & 0.0000 & 0.0010 & 0.0000 \\
\hline US-14 & & 0.1302 & 0.1790 & 0.0040 & 0.0000 & 0.0941 & 0.0100 & 0.0574 & 0.0050 & 0.0260 & 0.1122 & 0.0000 & 0.0007 & 0.0002 & 0.0000 & 0.3652 & 0.0000 & 0.0100 & 0.0000 & 0.0010 & 0.0050 \\
\hline US-15 & & 0.1000 & 0.1780 & 0.0050 & 0.0030 & 0.0500 & 0.0100 & 0.0200 & 0.0000 & 0.0000 & 0.1500 & 0.0000 & 0.0010 & 0.0002 & 0.0050 & 0.4659 & 0.0010 & 0.0100 & 0.0000 & 0.0010 & 0.0000 \\
\hline US-16 & & 0.1332 & 0.1881 & 0.0100 & 0.0008 & 0.0903 & 0.0100 & 0.0256 & 0.0000 & 0.0248 & 0.0630 & 0.0000 & 0.0000 & 0.0002 & 0.0000 & 0.4391 & 0.0000 & 0.0100 & 0.0000 & 0.0000 & 0.0050 \\
\hline US-17 & & 0.1166 & 0.1178 & 0.0000 & 0.0011 & 0.0622 & 0.0000 & 0.0536 & 0.0050 & 0.0300 & 0.0858 & 0.0108 & 0.0000 & 0.0002 & 0.0000 & 0.4999 & 0.0010 & 0.0100 & 0.0000 & 0.0010 & 0.0050 \\
\hline US-18 & & 0.1600 & 0.0913 & 0.0100 & 0.0000 & 0.0975 & 0.0000 & 0.0495 & 0.0000 & 0.0300 & 0.1341 & 0.0000 & 0.0010 & 0.0002 & 0.0000 & 0.4145 & 0.0010 & 0.0100 & 0.0000 & 0.0010 & 0.0000 \\
\hline US-19 & KRI-02 & 0.1447 & 0.1440 & 0.0070 & 0.0007 & 0.0823 & 0.0078 & 0.0364 & 0.0033 & 0.0199 & 0.1080 & 0.0021 & 0.0007 & 0.0002 & 0.0028 & 0.4281 & 0.0006 & 0.0080 & 0.0000 & 0.0007 & 0.0027 \\
\hline US-20 & KRI-03 & 0.1447 & 0.14440 & 0.0070 & 0.0007 & 0.0823 & 0.0078 & 0.0364 & 0.0033 & 0.0199 & 0.1080 & 0.0021 & 0.0007 & 0.0002 & 0.0028 & 0.4281 & 0.0006 & 0.0080 & 0.0000 & 0.0007 & 0.0027 \\
\hline US-21 & & 0.1422 & 0.1375 & 0.0038 & 0.0008 & 0.0845 & 0.0075 & 0.0300 & 0.0037 & 0.0178 & 0.1075 & 0.0050 & 0.0008 & 0.0002 & 0.0012 & 0.4495 & 0.0008 & 0.0054 & 0.0000 & 0.0003 & 0.0013 \\
\hline US-22 & & 0.1334 & 0.1169 & 0.0075 & 0.0008 & 0.0947 & 0.0075 & 0.0500 & 0.0037 & 0.0225 & 0.1178 & 0.0092 & 0.0003 & 0.0002 & 0.0012 & 0.4240 & 0.0008 & 0.0075 & 0.0000 & 0.0008 & 0.0013 \\
\hline US-23 & & 0.1450 & 0.1332 & 0.0075 & 0.0008 & 0.0762 & 0.0025 & 0.0350 & 0.0012 & 0.0225 & 0.1168 & 0.0050 & 0.0008 & 0.0002 & 0.0037 & 0.4446 & 0.0003 & 0.0025 & 0.0000 & 0.0008 & 0.0013 \\
\hline US-24 & $\begin{array}{l}\text { KRI-04 } \\
\end{array}$ & 0.1450 & 0.1225 & 0.0075 & 0.0008 & 0.0779 & 0.0075 & 0.0300 & 0.0037 & 0.0225 & 0.1157 & 0.0050 & 0.0008 & 0.0002 & 0.0037 & 0.4443 & 0.0008 & 0.0075 & 0.0000 & 0.0008 & 0.0038 \\
\hline US-25 & & 0.1158 & 0.1625 & 0.0075 & 0.0022 & 0.0854 & 0.0029 & 0.0500 & 0.0037 & 0.0216 & 0.1088 & 0.0145 & 0.0003 & 0.0002 & 0.0037 & 0.4079 & 0.0008 & 0.0075 & 0.0000 & 0.0008 & 0.0038 \\
\hline US-26 & & 0.1883 & 0.1069 & 0.0100 & 0.0055 & 0.0500 & 0.0000 & 0.0600 & 0.0050 & 0.0000 & 0.1102 & 0.0000 & 0.0000 & 0.0002 & 0.0000 & 0.3805 & 0.0300 & 0.0100 & 0.0000 & 0.0200 & 0.0235 \\
\hline US-27 & & 0.1040 & 0.0648 & 0.0000 & 0.0100 & 0.1518 & 0.0100 & 0.0600 & 0.0050 & 0.0000 & 0.1687 & 0.0000 & 0.0000 & 0.0002 & 0.0050 & 0.4004 & 0.0000 & 0.0000 & 0.0000 & 0.0200 & 0.0000 \\
\hline US-28 & & 0.1747 & 0.1796 & 0.0000 & 0.0000 & 0.0572 & 0.0100 & 0.0200 & 0.0000 & 0.0000 & 0.1336 & 0.0000 & 0.0000 & 0.0002 & 0.0050 & 0.3597 & 0.0300 & 0.0100 & 0.0000 & 0.0200 & 0.0000 \\
\hline US-29 & & 0.1000 & 0.17873 & 0.0100 & 0.0067 & 0.0500 & 0.0100 & 0.0600 & 0.0050 & 0.0000 & 0.1868 & 0.0000 & 0.0100 & 0.0002 & 0.0000 & 0.4526 & 0.0118 & 0.0096 & 0.0000 & 0.0000 & 0.0000 \\
\hline US-30 & & 0.1265 & 0.1819 & 0.0100 & 0.0082 & 0.0533 & 0.0100 & 0.0600 & 0.0000 & 0.0350 & 0.0500 & 0.0000 & 0.0000 & 0.0002 & 0.0050 & 0.3752 & 0.0300 & 0.0100 & 0.0000 & 0.0048 & 0.0400 \\
\hline US-31 & & 0.1267 & 0.1452 & 0.0000 & 0.0000 & 0.1545 & 0.0000 & 0.0491 & 0.0050 & 0.0074 & 0.0710 & 0.0000 & 0.0100 & 0.0002 & 0.0050 & 0.3860 & 0.0300 & 0.0100 & 0.0000 & 0.0000 & 0.0000 \\
\hline US-32 & & 0.1000 & 0.1901 & 0.0100 & 0.0000 & 0.0500 & 0.0000 & 0.0600 & 0.0000 & 0.0400 & 0.0750 & 0.0000 & 0.0100 & 0.0002 & 0.0050 & 0.4397 & 0.0000 & 0.0000 & 0.0000 & 0.0200 & 0.0000 \\
\hline $\begin{array}{l}\text { US-33 } \\
\end{array}$ & & 0.1134 & 0.0500 & 0.0000 & 0.0100 & 0.0500 & 0.0000 & 0.0200 & 0.0050 & 0.0400 & 0.1976 & 0.0097 & 0.0100 & 0.0002 & 0.0050 & 0.4591 & 0.0300 & 0.0000 & 0.0000 & 0.0000 & 0.00000 \\
\hline US-34 & & 0.1000 & 0.1369 & 0.0000 & 0.0000 & 0.0639 & 0.0100 & 0.0242 & 0.0050 & 0.0400 & 0.2000 & 0.0000 & 0.0000 & 0.0002 & 0.0000 & 0.3499 & 0.0300 & 0.0000 & 0.0000 & 0.0000 & 0.0400 \\
\hline US-35 & KRI-05 & 0.1002 & 0.1996 & 0.0100 & 0.0052 & 0.1135 & 0.0000 & 0.0200 & 0.0050 & 0.0400 & 0.0794 & 0.0000 & 0.0000 & 0.0002 & 0.0000 & 0.3800 & 0.0270 & 0.0000 & 0.0000 & 0.0200 & 0.0000 \\
\hline US-36 & & 0.1286 & 0.1551 & 0.0021 & 0.0051 & 0.0976 & 0.0052 & 0.0242 & 0.0005 & 0.0121 & 0.1252 & 0.0056 & 0.0100 & 0.0002 & 0.0000 & 0.3884 & 0.0001 & 0.0001 & 0.0000 & 0.0001 & 0.0400 \\
\hline US-37 & & 0.1000 & 0.0577 & 0.0100 & 0.0000 & 0.1700 & 0.0000 & 0.0200 & 0.0000 & 0.0000 & 0.1889 & 0.0000 & 0.0100 & 0.0002 & 0.0000 & 0.3733 & 0.0000 & 0.0100 & 0.0000 & 0.0200 & 0.0400 \\
\hline US-38 & & 0.1000 & 0.0731 & 0.0079 & 0.0000 & 0.0500 & 0.0100 & 0.0200 & 0.0000 & 0.0400 & 0.1972 & 0.0291 & 0.0100 & 0.0002 & 0.0050 & 0.3975 & 0.0300 & 0.0100 & 0.0000 & 0.0200 & 0.0000 \\
\hline US-39 & & 0.1155 & 0.1635 & 0.0000 & 0.0000 & 0.0750 & 0.0100 & 0.0600 & 0.0050 & 0.0000 & 0.0500 & 0.0183 & 0.0100 & 0.0002 & 0.0000 & 0.4246 & 0.0080 & 0.0000 & 0.0000 & 0.0200 & 0.0400 \\
\hline US-40 & & 0.1552 & 0.1700 & 0.0000 & 0.0043 & 0.1142 & 0.0100 & 0.0251 & 0.0000 & 0.0276 & 0.1013 & 0.0000 & 0.0100 & 0.0002 & 0.0000 & 0.3730 & 0.0000 & 0.0092 & 0.0000 & 0.0000 & 0.0000 \\
\hline US-41 & & 0.1000 & 0.1555 & 0.0100 & 0.0000 & 0.1553 & 0.0100 & 0.0372 & 0.0000 & 0.0000 & 0.0652 & 0.0000 & 0.0100 & 0.0002 & 0.0000 & 0.4265 & 0.0300 & 0.0000 & 0.0000 & 0.0000 & 0.0000 \\
\hline US-42 & & 0.2000 & 0.15619 & 0.0100 & 0.0000 & 0.0500 & 0.0100 & 0.0600 & 0.0000 & 0.0400 & 0.1882 & 0.0000 & 0.0100 & 0.0002 & 0.0000 & 0.3549 & 0.0000 & 0.0000 & 0.0000 & 0.0149 & 0.0000 \\
\hline US-43 & & 0.1717 & 0.0864 & 0.0100 & 0.0000 & 0.0886 & 0.0100 & 0.0490 & 0.0050 & 0.0081 & 0.1029 & 0.0020 & 0.0100 & 0.0002 & 0.0050 & 0.3970 & 0.0047 & 0.0048 & 0.0000 & 0.0045 & 0.0400 \\
\hline US-44 & KRI-06 & 0.1280 & 0.1259 & 0.0056 & 0.0031 & 0.0886 & 0.0064 & 0.0405 & 0.0025 & 0.0183 & 0.1273 & 0.00036 & 0.0067 & 0.0002 & 0.0022 & 0.3955 & 0.0162 & 0.0047 & 0.00000 & $\begin{array}{l}0.0102 \\
\end{array}$ & 0.0146 \\
\hline US-45 & KRI-07 & 0.1280 & 0.1259 & 0.0056 & 0.0031 & 0.0886 & 0.0064 & 0.0405 & 0.0025 & 0.0183 & 0.1273 & 0.0036 & 0.0067 & 0.0002 & 0.0022 & 0.3955 & 0.0162 & 0.0047 & 0.0000 & 0.0102 & 0.0146 \\
\hline & KRI-08 & 0.1269 & 0.1625 & 0.0025 & 0.0047 & 0.0800 & 0.0075 & 0.0300 & 0.0038 & 0.0300 & 0.1003 & 0.0081 & 0.0075 & 0.0000 & 0.0013 & 0.3949 & 0.0075 & 0.0075 & 0.0000 & 0.0150 & 0.0100 \\
\hline & KRI-09 & 0.1331 & 0.1434 & 0.0025 & 0.0041 & 0.0800 & 0.0025 & 0.0300 & 0.0038 & 0.0100 & 0.1121 & 0.0077 & 0.0075 & 0.0000 & 0.0013 & 0.4023 & 0.0075 & 0.0075 & 0.0000 & 0.0150 & 0.0300 \\
\hline & KRI-10 & 0.1250 & 0.0938 & 0.0075 & 0.0061 & 0.0800 & 0.0075 & 0.0311 & 0.0013 & 0.0114 & 0.1280 & 0.0075 & 0.0025 & 0.0000 & 0.0013 & 0.4558 & 0.0179 & 0.0025 & 0.0000 & 0.0107 & 0.0100 \\
\hline & KRI-11 & 0.1579 & 0.1399 & 0.0025 & 0.0025 & 0.0991 & 0.0045 & 0.0408 & 0.0013 & 0.0100 & 0.1066 & 0.0075 & 0.0025 & 0.0000 & 0.0013 & 0.3985 & 0.0075 & 0.0025 & 0.0000 & 0.0050 & 0.0100 \\
\hline & KRI-12 & 0.1282 & 0.1409 & 0.0075 & 0.0026 & 0.0848 & 0.0075 & 0.0387 & 0.0013 & 0.0300 & 0.0909 & 0.0087 & 0.0025 & 0.0000 & 0.0013 & 0.3951 & 0.0225 & 0.0025 & 0.0000 & 0.0050 & 0.0300 \\
\hline & KRI-13 & 0.1250 & 0.1079 & 0.0025 & 0.0039 & 0.0800 & 0.0075 & 0.0300 & 0.0013 & 0.0300 & 0.1180 & 0.0075 & 0.0075 & 0.0000 & 0.0038 & 0.4152 & 0.0075 & 0.0075 & 0.0000 & 0.0150 & 0.0300 \\
\hline & KRI-14 & 0.1312 & 0.1546 & 0.0025 & 0.0034 & 0.0800 & 0.0025 & 0.0500 & 0.0038 & 0.0300 & 0.0876 & 0.0110 & 0.0075 & 0.0000 & 0.0038 & 0.3929 & 0.0075 & 0.0075 & 0.0000 & 0.0142 & 0.0100 \\
\hline
\end{tabular}

a Note that the KRI glasses do not contain $\mathrm{RuO}_{2}$ due to funding limitations. 
Table 4-1. Target Compositions (as Mass Fractions) of the Test Matrix Glasses. (continued)

\begin{tabular}{|c|c|c|c|c|c|c|c|c|c|c|c|c|c|c|c|c|c|c|c|c|}
\hline Glass Identifiers & $\mathrm{Al}_{2} \mathrm{O}_{3}$ & $\mathrm{~B}_{2} \mathrm{O}_{3}$ & $\mathrm{CaO}$ & $\mathrm{Cr}_{2} \mathrm{O}_{3}$ & $\mathrm{Fe}_{2} \mathrm{O}_{3}$ & $\mathrm{~K}_{2} \mathrm{O}$ & $\mathrm{Li}_{2} \mathrm{O}$ & MgO & MnO & $\mathrm{Na}_{2} \mathrm{O}$ & NiO & $\mathrm{PbO}$ & $\mathrm{RuO}_{2}{ }^{\mathrm{a}}$ & $\mathrm{SO}_{3}$ & $\mathrm{SiO}_{2}$ & SrO & $\mathrm{TiO}_{2}$ & $\mathrm{UO}_{3}$ & $\mathrm{ZnO}$ & $\mathrm{ZrO}_{2}$ \\
\hline \begin{tabular}{l|l} 
& KRI-15 \\
\end{tabular} & 0.1623 & 0.1368 & 0.0025 & 0.0025 & 0.0800 & 0.0075 & 0.0332 & 0.0013 & 0.0111 & 0.1036 & 0.0075 & 0.0055 & 0.0000 & 0.0033 & 0.4156 & 0.0077 & 0.0025 & 0.0000 & 0.0070 & 0.0100 \\
\hline KRI-16 & 0.1250 & 0.0875 & 0.0025 & 0.0025 & 0.0800 & 0.0025 & 0.0492 & 0.0013 & 0.0100 & 0.0902 & 0.0075 & 0.0075 & 0.0000 & 0.0038 & 0.4625 & 0.0225 & 0.0075 & 0.0000 & 0.0150 & 0.0230 \\
\hline KRI-17 & 0.1286 & 0.1240 & 0.0075 & 0.0025 & 0.0859 & 0.0037 & 0.0388 & 0.0038 & 0.0182 & 0.1033 & 0.0075 & 0.0038 & 0.0000 & 0.0038 & 0.4087 & 0.0225 & 0.0025 & 0.0000 & 0.0050 & 0.0300 \\
\hline KRI-18 & 0.1338 & 0.1483 & 0.0075 & 0.0032 & 0.0891 & 0.0055 & 0.0352 & 0.0013 & 0.0203 & 0.1037 & 0.0083 & 0.0075 & 0.0000 & 0.0038 & 0.3875 & 0.0075 & 0.0025 & 0.0000 & 0.0050 & 0.0300 \\
\hline KRI-19 & 0.1354 & 0.1112 & 0.0025 & 0.0035 & 0.0981 & 0.0025 & 0.0437 & 0.0013 & 0.0300 & 0.1251 & 0.0103 & 0.0025 & 0.0000 & 0.0013 & 0.3875 & 0.0225 & 0.0075 & 0.0000 & 0.0050 & 0.0100 \\
\hline KRI-20 & 0.1440 & 0.1479 & 0.0075 & 0.0032 & 0.0864 & 0.0025 & 0.0300 & 0.0038 & 0.0100 & 0.1162 & 0.0078 & 0.0075 & 0.0000 & 0.0013 & 0.3918 & 0.0225 & 0.0025 & 0.0000 & 0.0050 & 0.0100 \\
\hline KRI-21 & 0.1352 & 0.1183 & 0.0075 & 0.0026 & 0.0906 & 0.0044 & 0.0329 & 0.0021 & 0.0127 & 0.1259 & 0.0105 & 0.0047 & 0.0000 & 0.0038 & 0.4017 & 0.0082 & 0.0032 & 0.0000 & 0.0057 & 0.0300 \\
\hline KRI-22 & 0.1574 & 0.1152 & 0.0025 & 0.0025 & 0.0800 & 0.0025 & 0.0500 & 0.0013 & 0.0100 & 0.1108 & 0.0075 & 0.0025 & 0.0000 & 0.0038 & 0.3890 & 0.0225 & 0.0075 & 0.0000 & 0.0050 & 0.0300 \\
\hline KRI-23 & 0.1626 & 0.1260 & 0.0025 & 0.0025 & 0.0800 & 0.0025 & 0.0300 & 0.0035 & 0.0100 & 0.1220 & 0.0075 & 0.0025 & 0.0000 & 0.0038 & 0.4095 & 0.0075 & 0.0025 & 0.0000 & 0.0150 & 0.0100 \\
\hline KRI-24 & 0.1265 & 0.0969 & 0.0075 & 0.0025 & 0.0830 & 0.0075 & 0.0377 & 0.0013 & 0.0188 & 0.1024 & 0.0075 & 0.0075 & 0.0000 & 0.0038 & 0.4372 & 0.0118 & 0.0061 & 0.0000 & 0.0120 & 0.0300 \\
\hline KRI-25 & 0.1506 & 0.1351 & 0.0028 & 0.0025 & 0.1123 & 0.0068 & 0.0375 & 0.0013 & 0.0112 & 0.1151 & 0.0075 & 0.0025 & 0.0000 & 0.0019 & 0.3878 & 0.0075 & 0.0025 & 0.0000 & 0.0050 & 0.0100 \\
\hline KRI-26 & 0.1048 & 0.1019 & 0.0100 & 0.0000 & 0.1114 & 0.0000 & 0.0600 & 0.0000 & 0.0000 & 0.1354 & 0.0300 & 0.0000 & 0.0000 & 0.0050 & 0.3959 & 0.0300 & 0.0000 & 0.0156 & 0.0000 & 0.0000 \\
\hline KRI-27 & 0.1044 & 0.1720 & 0.0100 & 0.0085 & 0.0987 & 0.0000 & 0.0573 & 0.0050 & 0.0066 & 0.1023 & 0.0047 & 0.0100 & 0.0000 & 0.0050 & 0.3556 & 0.0000 & 0.0100 & 0.0099 & 0.0000 & 0.0400 \\
\hline KRI-28 & 0.1835 & 0.0613 & 0.0000 & 0.0100 & 0.0500 & 0.0000 & 0.0572 & 0.0000 & 0.0385 & 0.1852 & 0.0000 & 0.0100 & 0.0000 & 0.0050 & 0.3650 & 0.0000 & 0.0100 & 0.0243 & 0.0000 & 0.0000 \\
\hline KRI-29 & 0.1427 & 0.1138 & 0.0000 & 0.0000 & 0.0565 & 0.0100 & 0.0200 & 0.0050 & 0.0000 & 0.2000 & 0.0300 & 0.0100 & 0.0000 & 0.0000 & 0.3500 & 0.0220 & 0.0100 & 0.0300 & 0.0000 & 0.0000 \\
\hline KRI-30 & 0.2000 & 0.1530 & 0.0075 & 0.0000 & 0.0551 & 0.0000 & 0.0579 & 0.0050 & 0.0000 & 0.0724 & 0.0000 & 0.0100 & 0.0000 & 0.0050 & 0.3574 & 0.0300 & 0.0000 & 0.0267 & 0.0200 & 0.0000 \\
\hline
\end{tabular}

\footnotetext{
a Note that the KRI glasses do not contain $\mathrm{RuO}_{2}$ due to funding limitations.
} 
WSRC-STI-2006-00205

Revision 0

This page intentionally left blank. 


\subsection{Summary}

High-level radioactive wastes are stored as liquids in underground storage tanks at SRS and the Hanford Reservation. These wastes are to be prepared for permanent disposal in a geologic repository by vitrification, creating a waste form with long-term durability. Some of the wastes at SRS, and many of those at Hanford, contain high concentrations of aluminum, chromium and sulfate. These elements make it more difficult to produce a waste glass with a high WL without crystallization occurring in the glass (either within the melter or upon cooling of the glass), potentially exceeding the solubility limit of critical components, having negative impacts on durability, and/or resulting in the formation of a sulfate salt layer on the molten glass surface. Although the overall scope of the task is focused on all three critical chemical components, the current work will primarily address the potential for crystallization (e.g., nepheline and/or spinel) in HLW glasses. Recent work at SRNL and by other groups has shown that nepheline, which is likely to crystallize in high-alumina glasses, has a detrimental effect on the durability of the glass.

The objective of this task is to develop glass formulations for specific DOE waste streams to avoid nepheline formation while meeting waste loading and waste throughput expectations, as well as satisfying critical process and product performance related constraints. Secondary objectives of this task are to assess the sulfate solubility limit for the DWPF composition and spinel settling for the WTP composition. SRNL has partnered with PNNL and KRI to complete this task.

Prior to demonstrating the acceptability of specific glass compositions for both DWPF and WTP, a more fundamental understanding of the compositional - property relationships within the glass regions of interest to both sites is warranted. Through this basic understanding, models can be generated to aid in the development of the specific glasses to demonstrate improved WLs for the specific streams of interest while still meeting both process and product performance criteria. To meet this initial goal (a more fundamental understanding), projected glass compositional regions that bound anticipated DWPF and WTP glass regions of interest were developed and used to generate glass compositions of interest for this study. A thorough statistical analysis was employed to allow for a wide range of waste glass compositions to be examined while minimizing the number of glasses that must be fabricated and tested in the laboratory. Two test matrices resulted from this process and are referred to throughout this report as the US test matrix and the KRI test matrix. A total of 75 glasses (66 unique compositions) define both matrices and will be used to assess critical compositional - property relationships from which the stated objectives can be met. Seven of the glasses will be fabricated and tested by both SRNL/PNNL and KRI to evaluate consistency between the labs (i.e., glasses targeting the same compositions are common to both matrices). SRNL/PNNL will fabricate and test a total of 45 glasses, and KRI will fabricate and test a total of 30 glasses. This report discussed the development of both the US and KRI test matrices.

The US test matrix glasses will be batched and melted following standard SRNL procedures, and testing will be completed to measure the chemical durability of each glass composition. Liquidus temperature, canister centerline cooled glass crystallinity, and crystal fraction as a function of temperature will be measured according to standard PNNL procedures. Fabrication and testing of the test matrix glasses at KRI will follow procedures that are equivalent to those at SRNL and PNNL. Data from the three laboratories will be monitored for consistency primarily by testing certified standard glasses and by fabricating and testing selected glasses with the same target compositions in both the US and KRI matrices (replication). A subsequent report will document the results of the experimental portion of this study. 
WSRC-STI-2006-00205

Revision 0

This page intentionally left blank. 
WSRC-STI-2006-00205

Revision 0

\subsection{References}

1. Edwards, T. B. and D. K. Peeler, "Nepheline Formation Potential in Sludge Batch 4 (SB4) and Its Impact on Durability: Selecting Glasses for a Phase 2 Study," U.S. Department of Energy Report WSRCTR-2005-00370, Revision 0, Westinghouse Savannah River Company, Aiken, South Carolina (2005).

2. Edwards, T. B., D. K. Peeler and K. M. Fox, "The Nepheline Discriminator: Justification and DWPF PCCS Implementation Details," U.S. Department of Energy Report WSRC-STI-2006-00014, Revision 0, Washington Savannah River Company, Aiken, South Carolina (2006).

3. Fox, K. M., T. B. Edwards, D. K. Peeler, D. R. Best, I. A. Reamer and R. J. Workman, "Durability and Nepheline Crystallization Study for High Level Waste (HLW) Sludge Batch 4 (SB4) Glasses Formulated with Frit 503," U.S. Department of Energy Report WSRC-STI-2006-00009, Revision 0, Washington Savannah River Company, Aiken, South Carolina (2006).

4. Fox, K. M., D. K. Peeler, T. B. Edwards, D. R. Best, I. A. Reamer and R. J. Workman, "Nepheline Formation Study for Sludge Batch 4 (SB4): Phase 3 Experimental Results," U.S. Department of Energy Report WSRC-TR-2006-00093, Revision 0, Washington Savannah River Company, Aiken, South Carolina (2006).

5. Li, H., P. Hrma, J. D. Vienna, M. Qian, Y. Su and D. E. Smith, "Effects of $\mathrm{Al}_{2} \mathrm{O}_{3}, \mathrm{~B}_{2} \mathrm{O}_{3}, \mathrm{Na}_{2} \mathrm{O}$, and $\mathrm{SiO}_{2}$ on Nepheline Formation in Borosilicate Glasses: Chemical and Physical Correlations," J. NonCrystalline Solids, 331 202-216 (2003).

6. Li, H., J. D. Vienna, P. Hrma, D. E. Smith and M. J. Schweiger, "Nepheline Precipitation in HighLevel Waste Glasses - Compositional Effects and Impact on the Waste Form Acceptability," Mat. Res. Soc. Proc., Vol. 465, pp. 261-268 (1997).

7. Peeler, D. K., T. B. Edwards, D. R. Best, I. A. Reamer and R. J. Workman, "Nepheline Formation Study for Sludge Batch 4 (SB4): Phase 2 Experimental Results," U.S. Department of Energy Report WSRC-TR-2006-00006, Revision 0, Washington Savannah River Company, Aiken, South Carolina (2006).

8. Peeler, D. K., T. B. Edwards and T. H. Lorier, "Nepheline Formation Potential in Sludge Batch (SB4) Glasses," U.S. Department of Energy Report WSRC-TR-2005-00153, Revision 0, Westinghouse Savannah River Company, Aiken, South Carolina (2005).

9. Peeler, D. K., T. B. Edwards, I. A. Reamer and R. J. Workman, "Nepheline Formation Study for Sludge Batch 4 (SB4): Phase 1 Experimental Results," U.S. Department of Energy Report WSRC-TR2005-00371, Revision 0, Westinghouse Savannah River Company, Aiken, South Carolina (2005).

10. Peeler, D. K. and T. B. Edwards, "Test Plan: Improved Alumina Solubility in US High Level Waste Glasses," U.S. Department of Energy Report SRNL-PSE-2006-00275, Washington Savannah River Company, Aiken, South Carolina 2006).

11. Barnes, B. O., "Pacific Northwest National Laboratory Quality Assurance Plan, Project 47607 - Task 6, LAW Glass Studies," U.S. Department of Energy Report PNNL-QAP-47607, Revision 0, Pacific Northwest National Laboratory, Richland, Washington (2006).

12. JMP $^{\mathrm{TM}}$, Ver. 5.1.2, [Computer Software] SAS Institute Inc., Cary, NC (2002). 
13. Taylor, A. S., T. B. Edwards, J. C. George, T. K. Snyder and D. K. Peeler, "The SRNL Composition Properties (ComPro ${ }^{\mathrm{TM}}$ ) Database," U.S. Department of Energy Report WSRC-RP-2004-00704, Revision 0, Westinghouse Savannah River Company, Aiken, South Carolina (2004).

14. Fox, K. M., D. K. Peeler and T. B. Edwards, "Request for QA Approval of Nepheline Database," U.S. Department of Energy Report SRNL-PSE-2006-00053, Washington Savannah River Company, Aiken, South Carolina (2006).

15. Cornel, J. A., Experiments with Mixtures: Designs, Models, and the Analysis of Mixture Data, John Wiley and Sons, New York (2002).

16. Meyer, R. K. and C. J. Nachtsheim, "The Coordinate Exchange Algorithm for Constructing Exact Optimal Designs," Technometrics, 37 [1] 60-69 (1995).

17. Piepel, G. F., S. K. Cooley and B. Jones, "Construction of a 21-Component Layered Mixture Experiment Design Using a New Mixture Coordinate-Exchange Algorithm," Quality Engineering, 17 579-594 (2005).

18. Vienna, J. D., "Test Plan: Task 6 Improved Alumina Solubility in US HLW Glasses," U.S. Department of Energy Report 47607-TP-06-01, Revision 0, Pacific Northwest National Laboratory, Richland, Washington (2006). 
WSRC-STI-2006-00205

Revision 0

This page intentionally left blank. 


\section{Distribution:}

\section{SRNL}

J.E. Marra, 773-A

R.E. Edwards, 773-A

D.A. Crowley, 999-W

T.B. Calloway, 999-W

J.R. Harbour, 773-42A

J.C. Marra, 773-42A

S.L. Marra, 773-A

R.C. Tuckfield, 773-42A

G.T. Chandler, 773-A

D.K. Peeler, 999-W

T.B. Edwards, 999-W

K.M. Fox, 999-W

C.C. Herman, 999-W

\section{PNNL}

J.D. Vienna, K6-24

A. Fluegel, K6-24

P.R. Bredt, K6-24

M.L. Elliott, K6-28

J.V. Crum, K6-24

D.S. Kim, K6-24

\section{KRI}

A. Aloy

A. Trofimenko

V. Below

O. Iskhakova

R. Soshnikov 